\title{
DICER1 Syndrome
}

National Cancer Institute

\section{Source}

National Cancer Institute. DICER1 Syndrome. NCI Thesaurus. Code C123317.

A rare, autosomal dominant inherited syndrome caused by mutations in the DICER1

gene. People with this syndrome are at an increased risk of developing pleuropulmonary

blastoma, cystic nephroma, Sertoli-Leydig cell tumor of the ovary, and multinodular goiter. 